\title{
THE INITIAL STAGE OF THE DEVELOPMENT OF THE SEMI-FREE POPULATION OF THE PRZEWALSKI'S HORSE IN THE ORENBURG STATE NATURE RESERVE (RUSSIA)
}

\author{
Rafilia T. Bakirova*, Tatjana L. Zharkikh, Evgeniy A. Bulgakov \\ Joint Directorate of State Nature Reserves «Orenburg» and «Shaitan-Tau», Russia \\ *e-mail: rbakirova@gmail.com
}

Received: 08.04.2019. Revised: 26.05.2019. Accepted: 02.06.2019.

\begin{abstract}
The Joint Directorate of the State Nature Reserves «Orenburg» and «Shaitan-Tau» (later - FSFI «Orenburg Reserves») elaborated the Programme on establishing a semi-free population of the Przewalski's horse in the Orenburg State Nature Reserve (Russia). It was launched in a $165.38 \mathrm{~km}^{2}$ natural steppe area called «Pre-Urals Steppe». The first stage of the Programme was funded by the UNDP/GEF Steppe Project 00072294 «Improving the Coverage and Management Efficiency of Protected Areas in the Steppe Biome of Russia» and the Ministry of Natural Resources and Ecology of the Russian Federation. The Pre-Urals Steppe was totally fenced to prevent the escape of Przewalski's horses from the strictly protected area. A Reintroduction Centre was constructed inside the fenced area. The Centre consists of permanent acclimatisation enclosures for horses, touristic infrastructure and a house for personnel (the ranger-station). All the work with Przewalski horses in the Pre-Urals Steppe are financed from the federal budget on permanent basis. A total of 36 Przewalski's horses were brought to the Pre-Urals Steppe from the Association pour le Cheval de Przewalski: TAKH, France, and the Hortobagy National Park, Hungary in 2015-2017. The horses were kept in the enclosures for about one year or more before being released into the main area. In March 2019, there were two free-roaming harems in the Pre-Urals Steppe. A third harem and a bachelor group are still kept in acclimatisation enclosures. One foal and six foals were born in 2016 and 2018 accordingly. The foaling rate was 50\% in 2018. One of the imported harem stallions is probably infertile, despite the fact that he was many times observed mating his females and in general, demonstrating normal sexual behaviour. The mortality of the imported Przewalski's horses is $8.3 \%$; foal mortality totals 28.6\%. There are 38 Przewalski's horses (16 males and 22 females) in the Pre-Urals Steppe area on 31 March 2019. The personnel of the Reintroduction Centre examine the whole Przewalski's horse population regularly. They identify the animals and watch their body condition and behaviour. The location of each free-roaming group is recorded with a GPS navigator. Any changes in the composition of the groups are recorded. Faeces are collected from each individual monthly for calculating parasite eggs in the samples. Every year a reserve stock of hay to feed the Przewalski's horses in the Pre-Urals Steppe is made to pass potential natural disaster such as severe drought, a snowy winter and/or heavy icing. Various scientific research including both Przewalski's horses and other components of local ecosystems are conducted in the Pre-Urals Steppe. The initial stage of the Programme has been successfully completed.
\end{abstract}

Key words: acclimatisation, demography, Equus ferus przewalskii, foaling rate, population management, mortality, reintroduction, transportation

The Przewalski's horse Equus ferus przewalskii Poliakov, 1881 is considered extinct in the wild after 1969. Fortunately, the species was preserved in captivity due to the extraordinary international cooperation between different nature conservation institutions (Boyd \& Houpt, 1994). A number of attempts to establish large free-ranging or semi-free populations of the Przewalski's horse has been made since the 1980s (Zimmermann, 2005). The information about successes and failures of the reintroduction projects adds value to the knowledge base about the possibilities of restore natural self-sustained populations of wild horses both within and outside their former area.

The Programme on establishing a semi-free population of the Przewalski's horse in Orenburg State Nature Reserve (Russia) was elaborated by Joint Directorate of State Nature Reserves «Orenburg» and «Shaitan-Tau» (later - FSFI «Orenburg Reserves»). It was launched in a natural steppe area called «Pre-
Urals Steppe». A Reintroduction Centre was built in 2015. Although less than four years have passed since the first Przewalski's horses set their feet on Orenburg land, some appreciable results have been achieved in the developing of the population. The aim of the article is to summarise the experience of the first years of the reintroduction of the Przewalski's horse to Orenburg steppes in Russia.

\section{Materials and Methods}

The $165.38 \mathrm{~km}^{2}$ Pre-Urals Steppe site is a former fire range in which military exercises were conducted between 1958 and 1998. Local people used some parts of the area mainly as grasslands for livestock grazing and hay stocking, some areas on rather flat topography were ploughed. The site became a part of Orenburg State Nature Reserve in 2015 and therefore acquired the status of strictly protected nature area on federal level. The site of 
about $16 \times 14 \mathrm{~km}$ is located $120 \mathrm{~km}$ from the city of Orenburg (Fig. 1). The geographic co-ordinates of outermost points of the border are $51.258631^{\circ} \mathrm{N}$, $56.188158^{\circ} \mathrm{E}$ (North); $51.106633^{\circ} \mathrm{N}, 56.204731^{\circ} \mathrm{E}$ (South); $51.188158^{\circ} \mathrm{N}, \quad 56.089783^{\circ} \mathrm{E}$ (West); $51.184489^{\circ} \mathrm{N}, 56.285638^{\circ} \mathrm{E}$ (East).

In the past 11 years, the annual temperature has averaged $+6,1^{\circ}$, the maximum was $+41,8^{\circ} \mathrm{C}$, the minimum was $-36.8^{\circ} \mathrm{C}$ (Table 1). The annual precipitation averaged $223 \mathrm{~mm}$ and varied between $71 \mathrm{~mm}$ in 2010 and $466 \mathrm{~mm}$ in 2016 (Fig. 2).

The Pre-Urals Steppe is situated in a steppe zone of the Pre-Urals (Orenburg region, Russia) within a subzone of herb-bunchgrass steppes (Ogureeva, 1999a,b). The flora includes 473 species of vascular plants, both zonal and edaphic (saline, sandy and stony) variants of steppe ecosystems are preserved in this area (Golovanov et al., 2018). Grasslands occupy more than $95 \%$ of the territory and represent 24 vegetation types of rich bunchgrass, psammophytic, petrophytic, halophytic steppes, and their anthropogenic derivatives (Fedorov et al., 2019b). A recent study revealed that in 2016 with normal precipitation, the vegetation productivity totalled 263 tons/ $\mathrm{km}^{2}$ including 184 tons $/ \mathrm{km}^{2}$ of preferred plants for Przewalski's horses (Fedorov et al., 2018). In winter the forage supply of pasture forage after a severe drought may reduce by 8 to 10 times (Fedorov et al., 2019a). The investigations on the carrying capacity of the area continue.

Totally, 12 species of amphibians and reptiles, more than 100 species of migratory and nesting birds, and about 30 mammal species have been registered in the Pre-Urals Steppe site. There are no dangerous predators for Przewalski's horses. The biggest mammal species is the roe deer Capreolus pygargus Pallas, 1771, who is not a food competitor for horses.

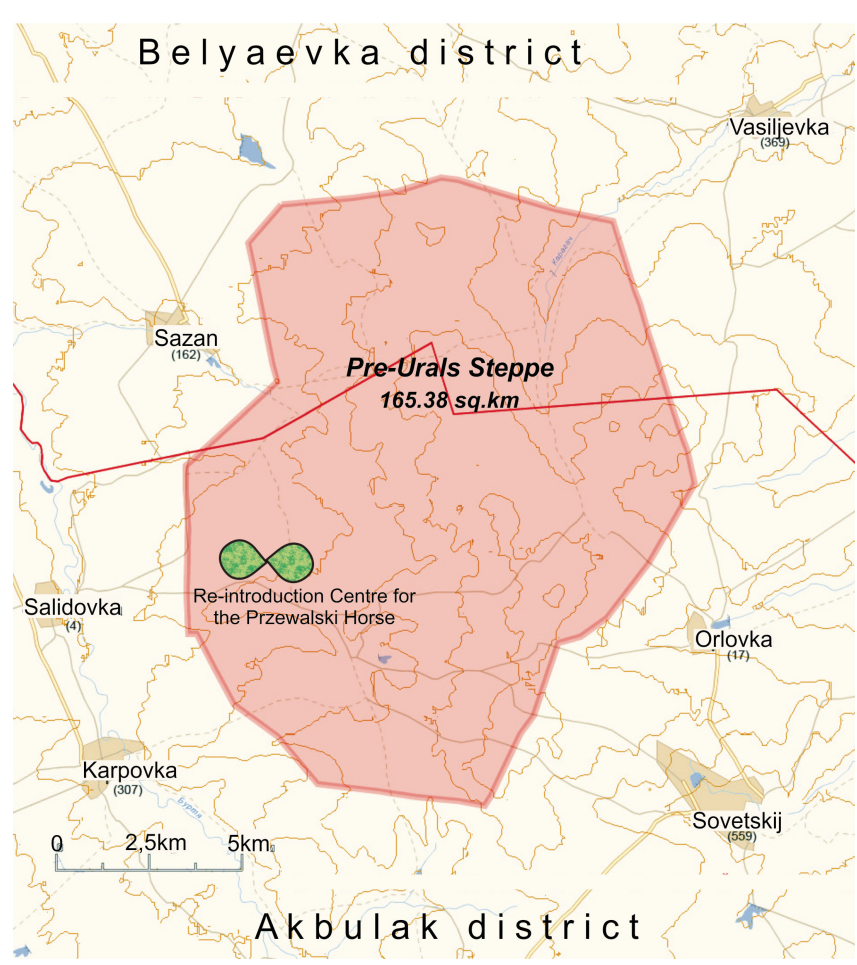

Fig. 1. Pre-Urals Steppe and surrounding settlements with the number of residents.

\section{Results}

\section{Preparation to reintroduction}

The Pre-Urals Steppe site is too small for a free self-sustained population of Przewalski's horses as they may leave the strictly protected area and vanish in the surrounding territories. To prevent this, in 2016, a $52 \mathrm{~km}$ wire mesh fence was constructed around the Pre-Urals Steppe site. All native steppe animals, except Przewalski's horses, may easily get through the mesh because of its large size at the bottom $(30 \times 30 \mathrm{~cm})$. For water there are three natural ponds and three dams were constructed in local gullies.

Table 1. Mean monthly temperature and precipitation between 2008 and 2018 (data are obtained from the meteorological station №35127 located in the Akbulak town, Orenburg region, Russia, $35 \mathrm{~km}$ south-west of Pre-Urals Steppe)

\begin{tabular}{|c|c|c|c|c|c|c|}
\hline Months & $\mathrm{t},{ }^{\circ} \mathrm{C}$ & $\operatorname{min~t},{ }^{\circ} \mathrm{C}$ & $\operatorname{max~t},{ }^{\circ} \mathrm{C}$ & Precipitation, $\mathrm{mm}$ & Average snow depth, $\mathrm{cm}$ & Maximum snow depth, cm \\
\hline $\mathrm{I}$ & -13.5 & -36.8 & +3.2 & 21 & 19.7 & 36 \\
\hline $\mathrm{II}$ & -12.2 & -35.4 & +3.8 & 15 & 26.7 & 44 \\
\hline $\mathrm{III}$ & -3.9 & -27.6 & +20.8 & 22.3 & 6.8 & 25 \\
\hline $\mathrm{IV}$ & +8.4 & -17.7 & +29.7 & 15 & - & - \\
\hline $\mathrm{V}$ & +16.6 & -5.6 & +34.3 & 23 & - & - \\
\hline VI & +21.5 & +1.8 & +41.0 & 15 & - & - \\
\hline VII & +23.8 & +5.8 & +41.8 & 15 & - & - \\
\hline VIII & +22.6 & +5.4 & +40.3 & 11 & 1.6 & - \\
\hline IX & +14.8 & -5.1 & +38.0 & 21 & 3.9 & 7 \\
\hline X & +5.7 & -11.7 & +25.2 & 22 & 10.2 & 16 \\
\hline XI & -1.5 & -24.9 & +14.0 & 20 & $\mathbf{1 7 . 9}$ & 29 \\
\hline XII & -8.8 & -31.2 & +7.0 & 27 & $\mathbf{1 8 . 9}$ & \\
\hline Average & $+\mathbf{6 . 1}$ & $\mathbf{- 3 6 . 8}$ & $+\mathbf{4 1 . 8}$ & & \\
\hline
\end{tabular}


A Reintroduction Centre for the Przewalski's Horse was constructed inside the fenced area of the Pre-Urals Steppe. It serves for acclimatisation of imported animals (founders of the semi-free population) and environmental education.

The Centre consists of permanent acclimatisation enclosures for horses, touristic infrastructure and a house for personnel (the ranger-station). Two round-shaped enclosures of $0.45 \mathrm{~km}^{2}$ each with natural steppe vegetation for two groups of Przewalski's horses are situated opposite to each other, several additional pens and a stable are between them (Fig. 3). The perimeter of each enclosure is $2300 \mathrm{~m}$. If they had been square-shaped the size would have been only $0.3 \mathrm{~km}^{2}$ each. The enclosures are fenced with a wire mesh of $2 \mathrm{~m}$ in height. Besides, an additional electric fence is set inside and outside of the enclosures' perimeter to prevent stallions fighting through the mesh. Each enclosure has a simple shelter as two perpendicular walls with a roof. There is an artesian well next to the enclosures; a set of hoses deliver water for animals to watering troughs.

Several additional pens and a stable with three boxes were designed to form new groups, to separate some individuals for treatment or relocation and some other manipulations. Their total size is about $1200 \mathrm{~m}^{2}$ (Fig. 4).

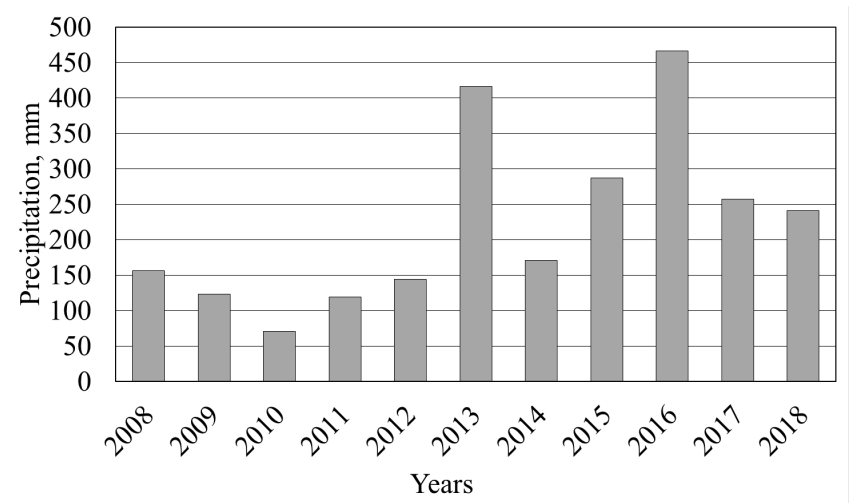

Fig. 2. Annual precipitation in Pre-Urals Steppe between 2008 and 2018.

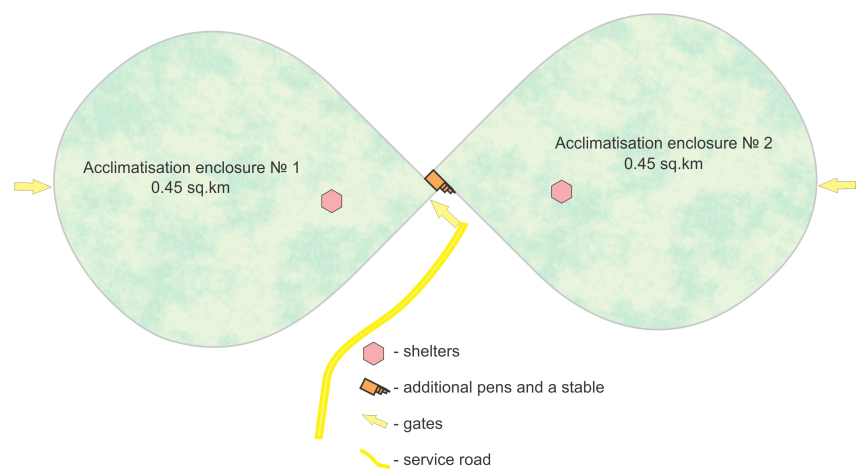

Fig. 3. Acclimatisation enclosures for Przewalski's horses.

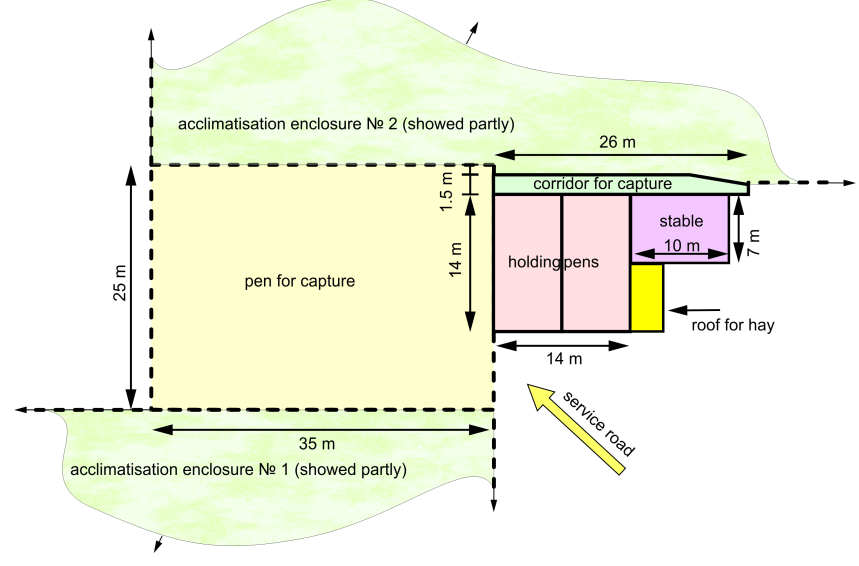

Fig. 4. Sketch of additional pens and stable.

At $500 \mathrm{~m}$ from the enclosures' entrance there is a ranger station supplied with electricity, water, two bedrooms, a field laboratory, a kitchen, a toilet, a septic system, and a sauna. A small visitor centre for tourists is next to the ranger station. The facilities allow year-round living and working space for 5 to 6 persons engaged in the work on rotation basis. There is an off the road car, an ATV, a snowmobile for the staff of the Reintroduction Centre use only, apart from the rangers' vehicles and two tractors.

All the work with Przewalski's horses in the Pre-Urals Steppe is financed by the federal budget on permanent basis.

\section{Selection of founders}

Founder horses of the new population must be healthy, have typical phenotype, and originate from different breeding lines. Przewalski's horses with fox-genes, white marks, and hanging mane must be excluded (Zimmermann, 2005). The chosen animals must be registered in the International Studbook and recommended for breeding by EEP. Captive-bred animals generally fare worse than wild-born counterparts after release (Zharkikh \& Yasynetska, 2005; Letty et al., 2007; Rummel et al., 2016). Until 2015, there were no large nature (semi-)reserves for wild horses Przewalski's horses in Russia. At present, local zoos have got no Przewalski's horses valuable in terms of their genetics.

That was why FSFI «Orenburg Reserves» looked for founders in European semi-reserves. We appreciate much Association pour le Cheval de Przewalski: TAKH (France) and personally Dr Claudia Feh who believed in the possibility of success of the Programme and was the first who agreed to send a group of Przewalski's horses to Orenburg 
State Nature Reserve in 2015. The Hortobagy National Park, Hungary supported the Programme granting 30 more horses in 2016 and 2017. A total of 36 Przewalski's horses were brought to the PreUrals Steppe (Table 2). There were two harems (breeding groups), two only-male groups and an only-female group transported. All the horses were born in populations with natural social structure and in fenced protected areas with natural grassy vegetation, the size of the areas is $6 \mathrm{~km}^{2}$ in France and $30 \mathrm{~km}^{2}$ in Hungary.

\section{Transportation and acclimatisation}

All the Przewalski's horses were brought to the Pre-Urals Steppe in October - November as autumn is the most comfortable period for the initial adaptation: cool weather and the absence of ticks and flies. Besides, this is out of the breeding season and the horses behaved calmer at that time.

Przewalski's horses intended to be transported to Russia were being loaded into transport boxes from dawn to dusk, then, were transported to an airport of the exporting country. They were released from the boxes in the Pre-Urals Steppe the next afternoon, thus, the animals spent about 20 hours to 30 hours in their boxes during the transportation. Upon arrival the horses were placed into acclimatisation enclosures with water-troughs, natural grass and hay. The horses were kept in the enclosures for about one year or more before being released into the main area of the Pre-Urals Steppe.

As a daily routine, the personnel of the Reintroduction Centre observes the horses thoroughly every day; evaluates their appearance, body condition and behaviour. They water the horses in the enclosures, give extra forage if necessary, provide some health care (e.g. give medicines with oats or autonomously via special sticks), and maintain the equipment in good working order.

\section{Formation of new groups and release}

The first group of Przewalski's horses consisted of a naturally established harem of 4 individuals and an adult female with her yearling offspring from another harem left in France. In the Reintroduction Centre, all the horses were consolidated in one harem with the use of a «mild» two-stage technic: first the stallion and the single mare with her offspring were placed in an isolated enclosure allowing them time to get acquainted, then all horses were united.

Harems were the first groups released from their acclimatisation enclosures in a year after transportation, on 3 October 2016 (French harem) and on 28 September 2017 (Hungarian har$\mathrm{em})$. Once the young male of the French harem reached the age of three years in 2017, he was expelled by the harem stallion. The youngster came to the acclimatisation enclosures and was walking all around until he had been lured to an additional pen. Then he was united with the existed bachelor group in the same way as the French harem: the two calmest males from the existed bachelor group were closed into the pen with the newcomer for a few days, then the consolidated group was released into the acclimatisation enclosure to adult males. The only-male group (bachelors) from the 2nd transport was still kept in the enclosure in order not to bother the breeding groups exploring new territories and adapting to semi-free conditions. While the only-female group of the $3^{\text {rd }}$ transport was located in a separate enclosure without a stallion until the next breeding season (spring 2018), the $2^{\text {nd }}$ only-male group was united with the existed bachelor group in the routine «mild» two-stage technic. First, the newcomers were introduced to the two calmest males in an isolated pen, then all bachelors consolidated into the acclimatisation enclosure.

Table 2. Age and sex of imported Przewalski's horses at the time of transport

\begin{tabular}{|c|c|c|c|c|c|}
\hline \multirow{2}{*}{$\begin{array}{c}\text { Date } \\
\text { of transfer }\end{array}$} & \multirow{2}{*}{ Place of birth } & \multicolumn{2}{|c|}{ Males (average age, full years ) } & \multirow{2}{*}{$\begin{array}{c}\text { Females } \\
\text { (average age, } \\
\text { year) }\end{array}$} & \multirow{2}{*}{ Total } \\
\hline & & harem stallion & other & & \\
\hline 18.10 .2015 & Le Villare semi-reserve, France & $1(9)$ & $\begin{array}{l}1 \text { (1 year } 4 \\
\text { months })\end{array}$ & $4(4.3)$ & 6 \\
\hline 20.11.2016 & Hortobagy National Park, Hungary & $1(6)$ & $5(3.2)$ & $8(2.5)$ & 14 \\
\hline 10.10 .2017 & Hortobagy National Park, Hungary & 0 & $4(2)$ & $12(2.1)$ & 26 \\
\hline & Total & $2(7.5)$ & $10(1.9)$ & $24(2.6)$ & 36 \\
\hline
\end{tabular}


In May 2018, an attempt was made to form the $3^{\text {rd }}$ harem. The strongest male who has the highest rank in the hierarchy was selected from the bachelor group. The male and two females from the only-female group were placed into an isolated pen and the new harem was released from their pen to the main Pre-Urals Steppe area two weeks later. In two days, the females left the stallion and joined the big Hungarian harem that had been ranging about the main area since September 2017. The abandoned stallion got five other females from the acclimatisation enclosure. However, he lost his females again five days later; the females joined the big Hungarian harem too. The unlucky stallion roamed the main area but did not succeed to lure any female from the free-roaming harem groups. He was let into the bachelors' enclosure in July 2018. In May, one more stallion was driven from the bachelor group to the neighbouring enclosure to the rest of the females to form the $3^{\text {rd }}$ harem intended to be kept in the acclimatisation enclosure for the next few years.

In January 2019, three bachelors were released from their enclosure to let them try to seize some females from existing free-roaming harems. In March, one of the males finally won a fight and became the harem stallion in the biggest group. Other males including the former harem stallion were lured back into the acclimatisation enclosure until the end of the snow season.

At present, there are two free-roaming harems in the Pre-Urals Steppe. The third harem and a bachelor group are still kept in acclimatisation enclosures.

\section{Dynamics of the population}

One of the French females was already pregnant at the time of transport, and foaled in May 2016 (Table 3). The foal died before the staff noticed it; its remains were found two months later and it was too late to determine the cause of its death. There have been no other births in the French harem since then. Probably the harem stallion is infertile despite the fact that he was many times observed mating his females and in general, demonstrating normal sexual behaviour.

There were six foals born in 2018 (Table 3). Foaling occurred between 2 May and 27 October. The total foaling rate was $50 \%$ in 2018 . Yet, if calculating only the females who could mate with the fertile Hungary harem stallion, the foaling rate was $60 \%$ including a foal out of a French female. In autumn 2017, two French females joined to the Hungarian harem for a while.
Table 3. Births in Pre-Urals Steppe on 31 March 2019

\begin{tabular}{|c|l|c|c|l|}
\hline Sex & Horse name & Date of birth & Date of death & Cause of death \\
\hline$?$ & & 17.05 .2016 & 17.05 .2016 & unknown \\
\hline M & Arnak & 02.05 .2018 & & \\
\hline M & Atas & 22.05 .2018 & & \\
\hline M & Argod & 08.06 .2018 & & \\
\hline M & Azarm & 18.09 .2018 & & \\
\hline F & Amaga & 14.10 .2018 & & \\
\hline F & & 27.10 .2018 & 29.10 .2018 & killed by an adult horse \\
\hline
\end{tabular}

A mare of a free-roaming Hungarian harem left her group on the day of foaling and was absent for the next two days. On the third day, she was found protecting the dead body of her foal against other members of her group. The autopsy discovered severe wounds (notable hematomas, ecchymoses and broken ribs) under the foal's skin; obviously it was killed by another horse. The foal mortality is $28.6 \%$.

On arriving from Hungary in 2017, two females looked a bit thin. Despite extra feeding (good quality hay, oats) they lost more weight. One of them died in December 2017, another one in March 2018. Post-mortem examination revealed bowel inflammation of unknown origin in both cases. Viola Kerekes, manager of the Przewalski's Horse population in the Hortobagy National Park in Hungary, reported several cases of death of their horses with the same symptoms in autumn 2017 and winter 2018. The causes of death were also unexplained. One female disappeared in June 2018 after being released from the acclimatisation enclosure to the main area, once the attempt to establish the third free-roaming group was made. Probably, the female died soon after release. The mortality of imported Przewalski's horses is $8.3 \%$.

Totally, there are 38 Przewalski's horses (16 males and 22 females) in the Pre-Urals Steppe area on 31 March 2019 (Fig. 5).

\section{Management of the population}

In general, the management of the Przewalski's horse population at FSFI «Orenburg Reserves» is patterned on the Hortobagy National Park (Hungary), Askania Nova Biosphere Reserve (Ukraine) and some other good European semi-reserves. The best practice is being disseminated and introduced.

The personnel of the Reintroduction Centre examine all the Przewalski's horse population regularly. The horses are given some oats (about 200-300 g per individual) once or twice a week. That is why 
they tolerate people and allow coming to a distance of dozens metres. The personnel identify the animals and watch their body condition and behaviour. The location of each free-roaming group is recorded with a GPS navigator. Any changes in the composition of the groups are recorded. Faeces are collected from each individual monthly for calculating parasite eggs in the samples; the analyses are made in a field laboratory of the ranger-station. The horses receive a deworming treatment once a year.

All the cases of births and deaths with postmortem examination if possible are registered. The catalogue of identity cards of the horses with their photos and descriptions is supplemented. Parentage of new-born foals is planned to be confirmed by DNA analyses from hair and faeces. Some of the foals are aimed to be marked. The data on the dynamics of the population are sent to the Studbook keeper (Prague Zoo, Czech Republic) and to the EEP-co-ordinator (Cologne Zoo, Germany) annually.

According to the vegetation productivity in the Pre-Urals Steppe, the carrying capacity of the whole territory is estimated at 200 to 300 horses. Every year a reserve stock of hay to feed Przewalski's horses in the Pre-Urals Steppe is made to pass potential natural disaster such as severe drought, a snowy winter and/or heavy icing. In January 2016, «winter $\mathrm{dzud}^{11}{ } \gg$ resulted from a short wintertime warming, followed by a return to sub-freezing temperatures. The snow melted and then got frozen again, creating an impenetrable icecover that prevented the imported Przewalski's horses from grazing, so they had to eat hay until April.

\footnotetext{
«Dzud» is a local term applying for the phenomenon of severe winters that kill large numbers of livestock occured periodically in Mongolia and Kazakhstan.
}

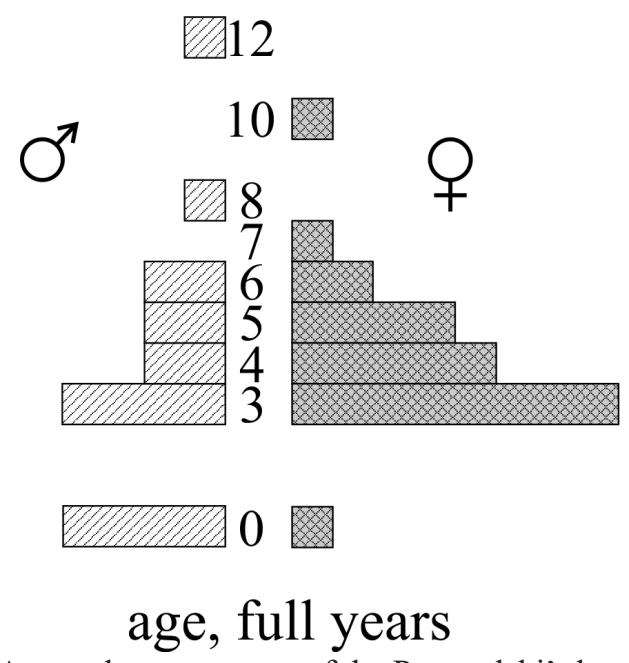

Fig. 5. Age and sex structure of the Przewalski's horse population on 31 March 2019.
FSFI «Orenburg Reserves» will control the number of Przewalski's horses much earlier than the carrying capacity is reached. Population size control measures will be taken if necessary (e.g. limitation of breeding by castration, porcine zona pellucida (PZP) vaccination and other possible and legal methods).

Various scientific research including both Przewalski's horses and other components of local ecosystems are conducted in the Pre-Urals Steppe. The Reintroduction Centre has become a popular touristic place where people come to watch wild horses in their natural habitats and get knowledge about steppe conservation. The stuff of the educational departure of FSFI «Orenburg Reserves» and the personnel of the Reintroduction Centre promote environmental education in the form of lectures, guided tours in the Pre-Urals Steppe, etc. About 1500 people, including tourists, media and scientists visited the Pre-Urals Steppe in 2016-2018.

\section{Discussion}

Developing the Programme on establishing a semi-free population of the Przewalski's horse, FSFI «Orenburg Reserves» has fully investigated the international experience and learned both positive and negative lessons from other reintroduction projects. Planning decisions for the Reintroduction Centre was aimed to include the most fitting elements from infrastructure designs of other such complexes, mainly, Askania Nova Zoo infrastructure as well as the methods of work with imported Przewalski's horses. It also saved funds as the initial active stage of any relocation project is the most cost consuming. Some other methods implemented in this project were based on previous 12-year work experience of T. Zharkikh in the project of establishing the free Przewalski horse population in the Chernobyl Exclusive Zone. There were for example the transportation and release in autumn, consolidation of groups and/or individuals. We consider all the above-mentioned to be a reason of the survival rate of the imported Przewalski's horses being high in comparison with some other projects. For example, the mortality within the first year after transportation varied between $33 \%$ and $26 \%$ in four large projects in Mongolia (Hustain Nuruu, Takhi Tal), Hungary (Pentezug), Ukraine (Chernobyl Exclusive Zone) (Zharkikh \& Yasynetska, 2005).

A low reproductive rate is usually anticipated over the first years of reintroduction as relocated animals need time for complete adaptation to the new environment. The foaling rate averaged $38.7 \%$ for the first five years in Xinjiang, China (Chen et al., 2008), 51.3\% for the first four years in Hustain Nuruu, Mongolia (Bou- 
man, 1998), 47\% for the first ten years in Takhiin Tal, Mongolia (Slotta-Bachmayr et al., 2004). Besides the continuing adaptation, there are some other reasons for the low foaling rate in Przewalski's females in the Pre-Urals Steppe. First, the obvious infertility of the French harem stallion. It is a challenge to put him away from his current group. Other stallions have failed to win a fight for his harem until present. Moreover, it seems that his females are reluctant to abandon him. The second possible reason of low fertility is that some Hungarian females were treated with the PZP vaccine before transportation. There is a lack of data about the influence of the PZP vaccine on reproductive ability of young nulliparous Przewalski's females. In the third place, it is the too large number of females in the freeroaming Hungarian harem. The females especially high-ranking ones often intervened between a female in heat and the stallion, showed aggression toward them and prevented their successful mating.

There are too little data to draw some conclusions about foal mortality in the Pre-Urals Steppe. However, infanticide is one of the common reasons of foal mortality in some populations of Przewalski's horses (Chen et al., 2008; Feh \& Munkhtuya, 2008; Dorj \& Namkhai, 2013). The personnel of the Reintroduction Centre especially focus on male behaviour; one of the bachelors with excessive aggressions towards other males is planned to keep in the acclimatisation enclosure as long as possible to prevent possible kill of youngsters born in free-roaming groups.

\section{Conclusions}

The initial stage of the Programme on establishing a semi-free population of the Przewalski's horse in Orenburg State Nature Reserve has been successfully completed:

- The necessary infrastructures were constructed; all the equipment was provided to organise yearround functioning of the Reintroduction Centre.

- Thirty-six founder horses from European semi-reserves were brought and acclimatised well.

- Two harems and some bachelors were released from the acclimatisation enclosures to establish a semi-free population; the first foals were born and grew up in the main area of the Pre-Urals Steppe.

- Routine monitoring and scientific research continue since 2015.

\section{Acknowledgements}

The first stage of the Programme was funded by the UNDP/GEF Steppe Project 00072294 «Improving the Coverage and Management Efficiency of Protected Areas in the Steppe Biome of Russia» and the Ministry of Natural Resources and Ecology of the Russian Federation. The staff members of FSFI «Orenburg Reserves» are involved in the Programme on establishing a semi-free population of the Przewalski's horse in Orenburg State Nature Reserve and do their best to develop it. In particular, we express our great appreciation to Vladimir Yu. Petrov for his valuable contribution to the success of the initial stage of the Programme, invaluable due to his dedicated efforts to guide safely Przewalski's horses through the challenges of their adaptation to severe environment of their new homelands.

\section{References}

Bouman I. 1998. The reintroduction of Przewalski's horses in the Hustain Nuruu Mountain Forest Steppe Reserve in Mongolia. Nederlandsche Commissie voor Internationale Natuurbescherming. Mededelingen. Vol. 32. 50 p.

Boyd L., Houpt K.A. (Eds). 1994. Przewalski's Horse: the History and Biology of an Endangered Species. New York: State University of New York Press. 313 p.

Chen J.L., Weng Q., Chao J., Hu D., Taya K. 2008. Reproduction and development of the released Przewalski's horses (Equus przewalskii) in Xinjiang, China. Journal Equine Science 19(1): 1-7. DOI: 10.1294/jes.19.1

Dorj U., Namkhai B. 2013. Reproduction and mortality of re-introduced Przewalski's Horse Equus przewalskii in Hustai National Park, Mongolia. Journal of Life Sciences 7(6): 623-629.

Fedorov N.I., Mikhailenko O.I., Zharkikh T.L., Bakirova R.T. 2018. Mapping of Vegetation with the Geoinformation System and Determining of Carrying Capacity of the Pre-Urals Steppe area for a Newly Establishing Population of the Przewalski Horse Equus ferus przewalskii at the Orenburg State Nature Reserve. In: IOP Conference Series: Earth and Environmental Science 107(1): 012100. DOI: 10.1088/1755-1315/107/1/012100

Fedorov N.I., Zharkikh T.L., Mikhailenko O.I., Bakirova R.T. Martynenko V.B. 2019a. Projection of changes in the productivity of plant communities in the Pre-Urals Steppe site of Orenburg Reserve in extreme drought conditions with the use of NDVI. Nature Conservation Research 4(Suppl.2): 104-110. DOI: 10.24189/ ncr.2019.044

Fedorov N.I., Zharkikh T.L., Mikhailenko O.I., Bakirova R.T. 2019b. The Use of NDVI for the Analysis of the Effect of Drought on Vegetation Productivity in the Pre-Urals Steppe Area Where a Population of the Przewalski Horse Equus Ferus Przewalskii Polj., 1881 Had Been Established. In: I. Bychkov, V. Voronin (Eds.): Information Technologies in the Research of Biodiversity. Cham: Springer. P. 1-7. DOI:10.1007/978-3-030-11720-7_1

Feh C., Munkhtuya B. 2008. Male infanticide and paternity analyses in a socially natural herd of Przewalski's horses: Sexual selection? Behavioural Processes 78(3): 335-339. DOI: 10.1016/j.beproc.2007.12.009

Golovanov Ya.M., Yamalov S.M., Lebedeva M.V., Bakirova R.T., Zharkikh T.L. 2018. Flora of Pre-Urals Steppe of Orenburg Reserve (Orenburg Region, Russian Federation). Bulletin of Bryansk dpt. of RBS 1(13): 10-21. [In Russian] 
Letty J., Marchandeau S., Aubineau J. 2007. Problems encountered by individuals in animal translocations: lessons from field studies. Ecoscience 14: 420-431. DOI: 10.2980/1195-6860(2007)14[420:PEBIIA]2.0.CO;2

Rummel L., Martınez-Abra1, A., Mayol J., Ruiz-Olmo J., Manas F., Jimenez J., Gomez J.A., Oro D. 2016. Use of wild-caught individuals as a key factor for success in vertebrate translocations. Animal Biodiversity Conservation 39(2): 207-220. DOI: 10.32800/ abc.2016.39.0207

Ogureeva G.N. (Ed.). 1999a. Zones and types of altitudinal zonality of Russia and adjacent territories. Map for the higher school. Scale 1:8000000. Moscow. 2 p. [In Russian]

Ogureeva G.N. (Ed.). 1999b. Zones and types of altitudinal zonality of Russia and adjacent territories. Explanatory text and legend to the map for the higher school. Scale 1:8000000. Moscow. 64 p. [In Russian]
Slotta-Bachmayr L., Boegel R., Kaczensky P., Stauffer C., Walzer C. 2004. Use of population viability analysis to identify management priorities and success in reintroducing Przewalski's Horses to southwestern Mongolia. Journal of Wildlife Management 68(4): 790-798. DOI: 10.2193/0022-541X(2004)068[0790:UOPVAT]2.0.CO;2

Zharkikh T.L., Yasynetska N.I. 2005. A review of some projects of re-introduction of the Przewalski's horse (Equus przewalskii) and recommendations on development of new populations. In: Ungulates in Zoos and Breeding Centres: Inter-department scientific and methodic articles. Moscow: Moscow Zoo. P. 33-60. [In Russian]

Zimmermann W. 2005. Przewalskipferde auf dem Weg zur Wiedereinbürgerung - Verschiedene Projekte im Vergleich. Zeitschrift des Kölner Zoo 4: 183-209.

Zimmermann W. (Ed.). 2005. EEP Asiatic Equids: Husbandry guidelines. $2^{\text {nd }}$, revised edition Cologne: Zoologischer Garten Koln. 159 p.

\title{
РЕЗУЛЬТАТЫ НАЧАЛЬНОГО ЭТАПА РАЗВИТИЯ ПОЛУВОЛЬНОЙ ПОПУЛЯЦИИ ЛОШАДЕЙ ПРЖЕВАЛЬСКОГО В ГОСУДАРСТВЕННОМ ПРИРОДНОМ ЗАПОВЕДНИКЕ «ОРЕНБУРГСКИЙ» (РОССИЯ)
}

\author{
Р. Т. Бакирова*, Т. Л. Жарких, Е. А. Булгаков
}

\author{
Объединенная дирекиия государственных природных заповедников «Оренбургский» и «Шайтан-Тау», Россия \\ *e-mail: rbakirova@gmail.com
}

\begin{abstract}
ФГБУ «Заповедники Оренбуржья» разработало Программу создания полувольной популяции лошади Пржевальского в Государственном природном заповеднике «Оренбургский». Программа была запущена на участке «Предуральская степь» площадью 165.38 км². Первый этап Программы финансировался Степным проектом ПРООН/ГЭФ 00072294 «Совершенствование системы и механизмов управления ООПТ в степном биоме России» и Министерством природных ресурсов и экологии Российской Федерации. Предуральская степь была полностью огорожена по периметру, чтобы предотвратить выход лошадей Пржевальского за пределы ООПТ. Внутри огороженной территории был построен Центр реинтродукции, состоящий из акклиматизационных загонов для лошадей, туристической инфраструктуры и домакордона для персонала. Вся работа с лошадьми Пржевальского в Предуральской степи финансируется из федерального бюджета на постоянной основе. В общей сложности 36 лошадей Пржевальского были привезены в Предуральскую степь из Ассоциации по лошади Пржевальского: ТАХ, Франция, и Национального парка Хортобадь, Венгрия, в 2015-2017 гг. Предусматривается, что лошади должны содержаться в загонах около года или более, прежде чем их выпустят на основную территорию Предуральской степи. К марту 2019 г. уже две гаремные группы обитали вне загонов. Третий гарем и холостяцкая группа до настоящего времени содержатся в акклиматизационных загонах. В 2016 г. родился жеребенок, в 2018 г. еще шесть. В 2018 г. доля ожеребивших кобыл составила 50\%. Один из завезенных гаремных жеребцов, вероятно, бесплоден, несмотря на то, что много раз наблюдалось его спаривание с кобылами, и в целом он демонстрирует нормальное сексуальное поведение. Смертность завезенных лошадей Пржевальского составляет 8.3\%, смертность жеребят - 28.6\%. На 31 марта 2019 г. в Предуральской степи обитают 38 лошадей Пржевальского (16 самцов и 22 самки). Персонал Центра реинтродукции регулярно осматривает всю популяцию лошадей Пржевальского, идентифицирует животных и следит за их состоянием и поведением. Местоположение каждой вольно пасущейся группы при встрече регистрируется GPS-навигатором. Любые изменения в составе групп фиксируются. Фекалии собираются от каждой особи ежемесячно для подсчета яиц паразитов в образцах фекалий. Каждый год создается запас сена для подкормки лошадей Пржевальского на случай потенциальных стихийных бедствий, такие как сильная засуха, снежная зима и/или обледенение. В Предуральской степи проводятся различные научные исследования, включающие лошадей Пржевальского и другие компоненты местных экосистем. Таким образом, начальный этап Программы успешно завершен.
\end{abstract}

Ключевые слова: Equus ferus przewalskii, акклиматизация, демография, коэффициент выжеребок, смертность, транспортировка, реинтродукция, управление популяцией 